\title{
PERBEDAAN EFEKTIFITAS TERAPI SEFT (SPIRITUAL EMOSIONAL FREEDOM TECHNIQUE) DAN TERAPI MUSIK KERONCONG TERHADAP TINGKAT DEPRESI PADA LANJUT USIA
}

\author{
Arif Nurma Etika ${ }^{1)}$ Sri Haryuni ${ }^{2)}$ Wiwin Sulistya ${ }^{3)}$ \\ 1) Fakultas Ilmu Kesehatan Universitas Kadiri \\ Email : arif_etika@yahoo.com \\ ${ }^{2)}$ Fakultas Ilmu Kesehatan Universitas Kadiri \\ Email : sisri_83@yahoo.co.id \\ ${ }^{3)}$ Fakultas Ilmu Kesehatan Universitas Kadiri \\ Email : tya_nersunair@yahoo.com
}

\begin{abstract}
Depression is an unfavorable condition for the elderly. When depression goes untreated, elderly can isolate themselves even allowed to end his life. Spiritual Emotional Freedom Technique (SEFT) and Keroncong music allegedly can be used as complementary therapy for elderly depression. This study aimed to determine the difference effect of Spiritual Emotional Freedom Technique (SEFT) and Keroncong music on elderly depression at Jombang geriatric service unit in Pare Kediri. The method used was a quasi-experimental, with a pretest and posttest design. In this study, respondents were grouped into two groups, SEFT intervention group $(\mathrm{n}=10)$ and Keroncong music Intervention group (10). In both groups was given four therapy sessions, within four weeks, each session is given therapy for 30 minutes.. In this study it was found that the decrease of score depression between pretest and posttest at SEFT therapy $(p=0,008)$ and keroncong music therapy $(\mathrm{p}=0,01)$. By unpaired $\mathrm{t}$ test, posttest obtained, the $\mathrm{p}$ value $(p=0,760)>0.05$ so that there is no significant difference between the posttest score in the SEFT Therapy group and the keroncong music therapy group. It can be concluded that SEFT and keroncong music reduce depression in elderly, but no more effective between SEFT and keroncong music reduce depression in elderly.
\end{abstract}

Keywords: Depression, Elderly, SEFT, keroncong music

\section{PENDAHULUAN}

Depresi merupakan hal yang tidak menguntungkan bagi lansia, karena depresi dapat memperpendek harapan hidup dengan memperburuk kemunduran fisik, selain itu dapat menurunkan kualitas hidup dan menghambat pemenuhan tugas perkembangan lansia. Bila depresi berlanjut dapat menguras emosi, dan juga apabila tidak ditangani bisa mengakibatkan lansia semakin mengisolasi diri bahkan memungkinkan untuk mengakhiri kehidupannya (Stanley $\&$ Beare, 2007; Cahoon, 2012).

Prevalensi depresi lansia di dunia adalah 10-15\% (Stanley \& Beare, 2007). Meskipun depresi sering terjadi pada lansia, tetapi kadang depresi ini sulit terdeteksi atau malah terabaikan. Hal tersebut dikarenakan isolasi sosial, sikap orang tua, penyangkalan, pengabaian terhadap proses penuaan normal serta persepsi yang keliru tentang depresi, yaitu memandang bahwa depresi merupakan bagian alami dari pertumbuhan lansia (Stanley \& Beare, 2007; Cahoon, 2012).

Ada beberapa cara untuk mengatasi depresi yaitu dengan psikofarmakologi, terapi elektrokonvulsif (ECT), intervensi psikososial, dan psikoterapi (Cahoon, 2012; Videbeck, 2008). Psikoterapi yang dapat menurunkan depresi adalah terapi Spiritual Emotional Freedom Technique (SEFT) dan terapi musik keroncong. SEFT merupakan penggabungan antara 
Spiritual Power dengan EFT yang menggunakan metode tapping pada delapan belas titik pada tubuh, yang dapat membantu pasien untuk mengurangi kecemasan, gangguan mental lebih cepat dan tanpa adanya resiko yang membahayakan (Zainuddin, 2006).

Berdasarkan penelitian Etika (2013) terapi SEFT dapat menurunkan depresi pada lansia di UPT PSLU Jombang di Pare Kediri, hal tersebut sesuai dengan Lane (2009) menyatakan bahwa pemberian rangsangan secara manual terhadap titik akupungtur dapat memproduksi opioid, serotonin dan gamaaminobutyric acid (GABA) serta memperbaiki regulasi kortisol. Neurochemical yang dihasilkan tersebut mampu menurunkan nyeri, menurunkan heart rate, menurunkan kecemasan, memperbaiki fight/flight/freeze response, memperbaiki regulasi sistem saraf outonom, dan memberikan perasaan yang nyaman.

Psikoterapi lainnya yang bisa menurunkan depresi adalah terapi musik keroncong, hal tersebut didasarkan pada penelitian Purbowinoto dan Kartinah (2011) yang menyatakan bahwa terapi musik keroncong dapat menurunkan tingkat depresi, karena intervensi musik keroncong akan meningkatkan serotonin yang akan mempengaruhi mood responden. Terapi musik dapat menghubungkan antara pikiran dan hati para penderita depresi sehingga mereka bisa membuka diri.

\section{HASIL DAN PEMBAHASAN}

HASIL

Karakteristik Responden

Tabel 1 Karakteristik responden $(\mathrm{N}=20)$.

\begin{tabular}{lcc}
\hline \multicolumn{1}{c}{ Variabel } & Frekuensi & Prosentase (\%) \\
\hline Jenis Kelamin & 2 & 10 \\
Laki-laki & 18 & 90 \\
Perempuan & & \\
Tingkat Pendidikan & 15 & 75 \\
Tidak Sekolah & 2 & 10 \\
SD & 2 & 10 \\
SMP & & \\
\hline
\end{tabular}

Tujuan penelitian ini adalah untuk mengetahui perbedaan efektifitas terapi Spiritual Emotional Freedom Technique (SEFT) dan terapi musik keroncong terhadap depresi pada Lansia di Unit Pelaksana Teknis Pelayanan Sosial Lanjut Usia (UPT PSLU) Jombang di Pare Kediri.

\section{METODE PENELITIAN}

Desain penelitian ini adalah quasi eksperimental, dengan pretest dan post test design. Pada penelitian ini responden yang memenuhi kriteria dikelompokkan menjadi dua kelompok, kelompok terapi SEFT $(n=10)$ dan kelompok terapi musik $(\mathrm{n}=10)$. Pada kedua kelompok dilakukan pretest dengan menggunakan geriatric depression scale (GDS) untuk menentukan tingkat depresi sebelum intervensi, pada kedua kelompok intervensi diberikan terapi sebanyak empat sesi, dalam empat minggu, setiap sesi diberikan terapi SEFT ataupun terapi musik selama 30 menit. Di akhir minggu keempat dilakukan posttest pada kedua kelompok.

Analisis dalam penelitian ini adalah univariat dan bivariate. Analisis bivariat dilakukan untuk mengetahui perbedaan tingkat depresi sebelum dan sesudah terapi dengan menggunakan wilcoxon test, karena ada data yang tidak terdistribusi normal. Sedangkan untuk perbedaan efektifitas terapi SEFT dan Terapi music keroncong dengan menggunakan uji $t$ tidak berpasangan. 


\begin{tabular}{lcc}
\hline \multicolumn{1}{c}{ Variabel } & Frekuensi & Prosentase (\%) \\
\hline SMU & 1 & 5 \\
Status Perkawinan & 1 & 5 \\
Menikah & 19 & 95 \\
Janda/Duda & & \\
\hline
\end{tabular}

Dari tabel di atas didapatkan gambaran bahwa dari 20 lansia di PSLU Jombang mayoritas berjenis kelamin perempuan $(90 \%)$. Tingkat pendidikan lansia di PSLU Jombang sebagian besar tidak sekolah (75\%). Status perkawinan sebagian besar Janda/Duda (95\%).

Tingkat Depresi Sebelum Intervensi

Tabel 2 Tingkat Depresi Responden ( $\mathrm{N}=20)$.

\begin{tabular}{lccc}
\hline \multicolumn{1}{c}{ Terapi } & Mean & Standar Deviasi & $95 \%$ CI \\
\hline SEFT & 9,70 & 3,368 & $7,29-12,11$ \\
Musik Keroncong & 10 & 3,162 & $7,74-12,26$ \\
\hline
\end{tabular}

Dari data di atas dapat diketahui bahwa menunjukkan rerata skor depresi lansia sebelum terapi SEFT di PSLU Jombang 9,70, 95\% skor depresi lansia antara 7, 29 sampai 12,11. Rerata skor depresi lansia sebelum terapi musik keroncong di PSLU Jombang 10, 95\% skor depresi lansia antara 7,74 sampai 12,26

Tingkat Depresi sesudah Intervensi

Tabel 3 Skor Depresi Lansia setelah terapi di PSLU Jombang Juli 2015 dengan

\begin{tabular}{lccc}
\multicolumn{4}{c}{$\mathrm{n}=(20)$} \\
\multicolumn{1}{c}{ Terapi } & Mean & Standar Deviasi & $95 \%$ CI \\
\hline SEFT & 3,80 & 1,989 & $2,38-5,22$ \\
Musik Keroncong & 4,30 & 2,541 & $2,48-6,12$
\end{tabular}

Tabel 3 menggambarkan rerata skor depresi lansia setelah terapi SEFT di PSLU Jombang 3,80, 95\% skor depresi lansia antara 2,38 sampai 5,22. Rerata skor depresi lansia setelah terapi musik keroncong di PSLU Jombang 4,30, 95\% skor depresi lansia antara 2,48 sampai 6,12 .

Perubahan skor depresi lansia sebelum dan sesudah terapi SEFT dan terapi musik keroncong

Tabel 4 Perubahan skor depresi lansia sebelum dan sesudah terapi SEFT di di PSLU Jombang Juli 2015 dengan $\mathrm{n}=(20)$

\begin{tabular}{lccc}
\hline & $\mathrm{N}$ & $\%$ & $\mathrm{P}$ \\
\hline Peningkatan & 0 & 0 & $0,008^{*}$ \\
Penurunan & 9 & 90 & \\
Sama & 1 & 10 & \\
\hline
\end{tabular}

*Bermakna pada $\alpha=0,05$

Dari data di atas, menunjukkan bahwa hasil uji statistik dengan wilcoxon signed rank test didapatkan ada penurunan yang signifikan skor depresi lansia sebelum dan sesudah terapi SEFT. Skor Depresi lansia yang mengalami peningkatan $0(0 \%)$, penurunan sebanyak 9 (90\%), yang tetap $1 \quad(10 \%)$. 
Perubahan skor depresi sebelum dan sesudah terapi

Tabel 5 Perubahan skor depresi lansia sebelum dan sesudah terapi musik keroncong di di PSLU Jombang Juli 2015 dengan $n=(20)$

\begin{tabular}{lccc}
\hline & $\mathrm{N}$ & $\%$ & $\mathrm{P}$ \\
\hline Peningkatan & 1 & 10 & $0,01^{*}$ \\
Penurunan & 9 & 90 & \\
Sama & 0 & 0 & \\
\hline
\end{tabular}

*Bermakna pada $\alpha=0,05$

Tabel 5 menunjukkan bahwa hasil uji statistik dengan wilcoxon signed rank test didapatkan ada penurunan yang signifikan skor depresi lansia sebelum dan sesudah terapi musik keroncong. Skor Depresi lansia yang mengalami peningkatan 1 (10\%), penurunan sebanyak $9(90 \%)$, yang tetap $0(0 \%)$.

Perbedaan efektifitas terapi SEFT dan terapi musik keroncong dalam menurunkan skor depresi lansia.

Tabel 6 Perbedaan efektifitas antara terapi SEFT dan musik keroncong di di PSLU Jombang Juli 2015 dengan $n=(20)$

\begin{tabular}{lcc}
\hline \multicolumn{1}{c}{ Kelompok } & Sebelum $(\mathrm{p})$ & Sesudah $(\mathrm{p})$ \\
\hline Terapi SEFT & $0,969^{*}$ & $0,760^{*}$ \\
Terapi musik keroncong & & \\
\hline$*$ Bermakna pada $0=0,05$ &
\end{tabular}

*Bermakna pada $\alpha=0,05$

Tabel 6 menunjukkan bahwa hasil uji statistik dengan mann whitney $u$ test didapatkan tidak ada perbedaan yang signifikan skor depresi lansia setelah terapi SEFT dan terapi musik keroncong.

\section{PEMBAHASAN}

\section{Interpretasi dan diskusi hasil}

Data hasil penelitian ini dianalisis menggunakan analisis univariat dan bivariat. Dalam penelitian ini, karakteristik responden yang dilakukan terapi SEFT dan terapi musik keroncong baik dalam hal usia, lama tinggal di panti, jenis kelamin, status pendidikan dan status perkawinan mempunyai karakteristik yang sama, sehingga dapat diasumsikan bahwa dua kelompok tersebut berasal dari base line yang sama, sehingga diharapkan ketika ada perubahaan skor depresi dari penelitian ini adalah betul-betul dari intervensi yang dilakukan. Selain itu, pengendalian faktor perancu juga dilakukan, yaitu pada responden tidak diberikan perlakuan selain perlakuan yang ada dalam penelitian ini. Sedangkan analisis bivariat digunakan untuk mengetahuan pengaruh
Hal ini bisa ditarik kesimpulan bahwa tidak ada perbedaan efektifitas antara terapi SEFT dan terapi musik keroncong dalam menurunkan depresilansia.

terapi SEFT dan terapi musik keroncong terhadap penurunan depresi lansia serta perbedaan efektifitas antara terapi SEFT dan terapi musik keroncong dalam menurunkan depresi lansia. Pembahasan selanjutnya akan dijelaskan secara terperinci pada sub bab sebagai berikut:

\section{Gambaran Skor Depresi Lansia di PSLU Jombang sebelum terapi}

Hasil penelitian menunjukkan skor depresi lansia sebelum terapi adalah 9,70 dan 10. Skor depresi lansia termasuk dalam kategori depresi berat (more severe depression. Yesavage membagi skala depresi menjadi tiga yaitu skor 0-4 artinya normal, skor 5-9 mild depression (depresi ringan), skor 10-15 more severe depression. Gejala depresi pada lansia di tempat penelitian ditunjukkan dengan lansia tampak murung, sedih, malas dan nafsu makan berkurang. Data sibjektif diperoleh peneliti melalui wawancar 
dengan menggunakan skala depresi pada lansia.

Kondisi depresi yang dialami lansia di UPT PSLU ini dikarenakan stressor psikososial, diantaranya hubungan dengan keluarga yang kurang baik, dan lansia yang tinggal di panti sudha tidak produktif secara finansial. Hal ini sejalan dengan penelitian Jayanti, Sedyowinarso, dan Madyaningrum (2008) di panti wredha "Wiloso Wredho" yang menyatakan faktor stressor psikososial berpengaruh secara signifikan terhadap tingkat depresi lansia di panti. Dewi, Dharmono, Heriawan, Aries dan Ariawan (2007) mengungkapkan hal senada bahwa faktor resiko yang berperan terhadap terjadinya depresi adalah lama rawat, stressor psikososial, dan status perkawinan janda/duda. Karakteristik Demografi dari hasil penelitian ini menunjukkan mayoritas lansia berjenis kelamin perempuan dan berstatus janda. Hal ini menjadi faktor yang menimbulkan depresi. Penelitian Trilistya (2006) tentang tingkat depresi korban tanah longsor di Banjar Negara menunjukkan ada hubungan yang bermakna antara jenis kelamin, dan status pernikahan dengan terjadinya depresi.

Hasil wawancara peneliti dengan beberapa responden dan penjelasan petugas panti, lansia yang tinggal di panti merupakan lansia yang terlantar dan jarang dijenguk oleh keluarga. Avritania, Indriati dan Supriadi (2011) menyatakan bahwa semakin tinggi perawatan keluarga dan dukungan sosial keluarga maka semakin rendah resiko depresi yang dialami lansia. Hal ini mendukung hasil penelitian ini yaitu tingkat depresi lansia berat. Hal tersebut didukung oleh Stanley dan Beare (2007); Cahoon (2012) yang menyatakan bahwa depresi merupakan hal yang tidak menguntungkan bagi lansia, karena depresi dapat memperpendek harapan hidup dengan memperburuk kemunduran fisik, menurunkan kualitas hidup dan menghambat pemenuhan tugas perkembangan lansia. Apabila depresi berlanjut dapat menguras emosi, dan juga jika tidak ditangani bisa mengakibatkan lansia semakin mengisolasi diri bahkan memungkinkan untuk mengakhiri kehidupannya.

\section{Gambaran Skor Depresi Lansia di PSLU Jombang setelah terapi}

Hasil penelitian menunjukkan skor depresi lansia setelah terapi SEFT dan terapi musik keroncong berada pada rerata skor 3,80-4,30. Berdasarkan tingkat depresi ini termasuk dalam kategori normal. Hal ini menunjukkan terjadinya penurunan tingkat depresi lansia dari berat menjadi normal.

\section{Perbedaan skor depresi lansia sebelum dan sesudah terapi SEFT dan terapi musik keroncong}

Hasil penelitian menunjukkan ada penurunan yang bermakna skor depresi sebelum dan sesudah terapi SEFT. Responden yang mengalami penurunan skor depresi sembilan (90\%), dan yang tetap satu (10\%). Terapi SEFT mampu menurunkan skor depresi lansia karena SEFT mempunyai nilai Spiritual, yaitu penekanan kepasrahan dan keikhlasan pada Tuhan serta tapping pada beberapa titik akupunktur yang dapat memberikan perasaan rileks bagi tubuh (Zainuddin, 2012). Keikhlasan dan kepasrahan tersebut ketika diucapkan secara khusu' akan menjadi sarana untuk meditasi. Hal ini senada dengan Jantos dan Kiat (2007) bahwa doa merupakan transedental meditasi, sedangkan meditasi dapat menimbulkan perubahan pada kondisi fisik maupun psikis, diantaranya penurunan denyut jantung, penurunan tekanan darah, melambatnya nafas, ketenagaan dan kedamaian. Hal senada juga diungkapkan Bakara (2012) yang menyatakan bahwa pemberian intervensi SEFT dapat menurunkan tingkat depresi, kecemasan, dan stres pada pasie SKA. Pengaruh tersebut dapat memberikan efek ketenangan. Kurnianto, Purwaningsih dan 
Nihayati (2011) menyatakan bahwa bimbingan spiritual, khususnya dengan agama Islam mempunyai dampak yang kuat dalam menurunkan skala depresi.

Terapi SEFT juga melakukan tapping pada 18 titik yang merupakan titik kunci dari "The Mayor Energy Meridians". Titik kunci tersebut jika diketuk beberapa kali akan berdampak ternetralisirnya gangguan emosi atau rasa sakit yangdirasakan (Zainuddin, 2012). Lae (2009) menyatakan pemberian rangsangan secara manual terhadap titik akupunctur dapat memproduksi opioid, serotonin dan gama-aminobutyric acid (GABA) serta memperbaiki regulasi kortisol. Neurochemical yang dihasilkan tersebut mampu menurunkan nyeri, menurunkan heart rate, menurunkan kecemasan, memperbaiki fight/flight/freeze respon, memperbaiki regulasi sistem saraf otonom, dan memberikan perasaan yang nyaman.

Hal senada juga disampaikan oleh Han (2004) yang menyatakan pemberian elektroakupunctur pada titik akupunctur dengan $2 \mathrm{~Hz}$ mampu meningkatkan pengeluaran enkephalin, $\beta$ endorphin, dan endomorphin, pemberian $100 \mathrm{~Hz}$ merangsang keluarnya dynorphin. Hal tersebut terjadi karena neuropeptida yang ada di CNS dapat digerakkan oleh rangsangan elektrik yang dilakukan pada area perifer. Church, Youth \& Brooks (2012) menyatakan bahwa kelompok intervensi yang diberikan terapi EFT terjadi penurunan yang signifikan terhadap tingkat kecemasan, depresi dan kadar kortisol di air ludah responden.

Pada akhir terapi SEFT responden diminta nafas dalam sambil mengucapkan syukur, serta disugesti bahwa ketika menarik nafas, responden memasukkan energy positif dan ketika menghembuskan nafas, diberikan sugesti bahwa responden mengeluarkan hal negative dari tubuhnya. Nafas dalam yang dilakukan dapat membuat sensasi rileks dan menghilangkan kepenatan yang ada. Hal tersebut didukung oleh Davis,
Eselman, Mc kay (2000) yang menyatakan bahwa nafas dalam dapat mengurangi stres dan depresi.

Hasil penelitian dengan terapi musik keroncong menunjukkan bahwa penurunan yang signifikan skor depresi lansia sebelum dan sesudah terapi musik keroncong. Mayoritas responden mengalami penurunan skor depresi sebanyak 9 (90\%), meskipun ada satu responden yang mengalami peningkatan sebanyak 1 (10\%). Mayoritas responden mengalami penurunan skor depresi akan tetapi ada satu responden yang mengalami peningkatan. Hal ini terjadi karena responden tersebut tidak menyukai musik keroncong dan pada saat penelitian berlangsung dia cenderung menyendiri dan kurang bisa menikmati music dan kebersamaan dengan temantemannya.

Djohan (2006) menyatakan bahwa pemberian terapi musik keroncong dengan melibatkan responden untuk ikut bernyanyi adalah membantu mengekspresikan perasaan, membantu rehabilitasi atas fisik, memberi pengaruh positif terhadap kondisi suasana hati dan meningkatkan memori, serta menyediakan kesempatan yang unik untuk berintreaksi dan membangun kedekatan emosional. Sehingga diharapkan dapat membantu mengatasi stress, mencegah penyakit dan meringankan rasa sakit.

Hasil penelitian ini sejalan dengan Atwater (2009 yang menyatakan pemberian musik keroncong dapat mempengaruhi gelombang otak menuju gelombang otak yang diinginkan. Prinsip pemberian terapi keroncong adalah dengan memberikan suara yang berbeda tempo irama lagu, dan dapat mempengaruhi telinga dan otak kemudian akan menangkap selisih dari perbedaan frekuensi tersebut kemudian mengikutinya sebagai gelombang otak. Mekanisme ini disebut dengan FFR (Frequency Following Response) dan terjadi di dalam otak, tepatnya di dua 
superior olivary nuclei. FFR didefinisikan sebagai penyesuaian frekuensi gelombang otak oleh karena respon dari stimulus auditori dan mendorong perubahan gelombang otak secara keseluruhan serta tingkat kesadaran ( Atwater, 2009).

Penelitian Purbowinoto \& Kartinah di PSTW Unit Budi Luhur Bantul Yogyakarta menunjukkan hasil yang senada bahwa pemberiaan terapi musik keroncong dapat menurunkan tingkat depresi, secara bermakna $(\mathrm{p}<0,05)$ karena intervensi musik keroncong akan meningkatkan produksi serotonin yang bertanggung jawab terhadap perubahan mood responden.

\section{Perbedaan efektifitas terapi SEFT dan terapi musik keroncong dalam menurunkan skor depresi lansia.}

Hasil penelitian menunjukkan tidak ada perbedaan efektifitas terapi SEFT dan terapi musik keroncong dalam menurunkan skor depresi lansia. Hal ini terjadi karena terapi SEFT dan terapi musik keroncong sama-sama mampu menurunkan skor depresi lansia. Meskipun pada setelah terapi SEFT ada 90\% responden yang mengalami penurunan dan $10 \%$ yang tetap sedangkan pada terapi musik keroncong ada $90 \%$ responden yang mengalami penurunan dan $10 \%$ yang mengalami peningkatan. Akan tetapi setelah dilakukan uji statistik dengan Mann Whitney U Test menunjukkan tidak ada perbedaan efektifitas yang bermakna antara terapi SEFT dan terapi musik keroncong dalam menurunkan skor depresi lansia.

\section{KESIMPULAN}

Hasil penelitian skor awal depresi sebelum terapi SEFT mempunyai rerata 9,70 (tingkat depresi berat). Skor awal sebelum terapi musik keroncong mempunyai rerata 10 (tingkat depresi berat). Setelah dilakukan terapi SEFT terjadi penurunan skor menjadi rerata
3,80 (normal) dan skor setelah terapi musik keroncong terjadi penurunan skor depresi menjadi 4,30 ( normal).

Hasil uji statistik dengan wilcoxon signed rank test menunjukkan ada penurunan yang siginifikan skor depresi sebelum dan sesudah terapi SEFT ( $p$ value $=0,008)$. Ada penurunan yang siginifikan skor depresi sebelum dan sesudah terapi musik keroncong ( $p$ value $=0,01)$. Hasil analisis dengan Mann Whitney U Test menunjukkan tidak ada perbedaan yang signifikan efektifitas terapi SEFT dan terapi musik keroncong dalam menurunkan skor depresi lansia $(p$ value $=0,760$ ).

Berdasarkan simpulan di atas, maka saran dalam penelitian ini adalah pemanfaatan SEFT dan terapi music keroncong bagi perawat komunitas dan perawat jiwa dalam memandirikan pasien dalam mengatasi permasalahannya, khususnya untuk menangani depresi. Selain itu di panti dapat dilakukan terapi music keroncong ataupun SEFT sebagai sarana relaksasi bagi lansia, sehingga menurunkan angka depresi.

\section{DAFTAR PUSTAKA}

Avritania, Indriati \& Supriadi. 2011. Hubungan perawatan keluarga dan dukungan sosial keluarga dengan depresi lansia di kelurahan Kembang Arum Semarang. Artikel Ilmiah Stikes Telogorejo Semarang

Bakara, D.M. 2012. Pengaruh intervensi Spiritual Emotional Freedom Technique (SEFT) terhadap tingkat depresi, kecemasan, dan stres pada pasien Sindrom Koroner Akut (SKA) Non Percutaneus Coronary Intervention (PCI) di RSUP Dr. Hasan Sadikin Bandung. Tesis Fakultas Keperawatan Unpad

Cahoon, CG. 2012. Depresssion in older adults a nurse's guide to recognition and treatment. 
American Journal of Nursing, 112(11): 22-30

Church, Yount \& Brooks. 2012. The effect of Emotional Freedom Techniques (EFT) on Stress Biochemistry: A Randomized Controlled Trial. Journal of Nervous and Mental Desease, 200(10): 891-896. Doi: 10.1097/NMD.0b013e31826b9fc1

Davis, Eselman \& Mc Key. 2000. The relaxation \& stress reduction workbook, 5th (ed.). Oakland, CA: New Harbinger Publications, Inc.

Dewi, S.Y., Dharmono, S., Heriawan, C., Aries, W., \& Ariawan, I.2007. Faktor resiko yang berperan terhadap terjadinya depresi pada pasien geriatri yang dirawat di RS. Ciptomangunkusumo.Cermin Dunia Kedokteran 156: 117-123

Djohan.2006.Terapi music"Teori dan Aplikasi”. Galang Press: Yogyakarta

Etika A.N.2013. Pengaruh Intervensi Spiritual Emotional Freedom Tehnique (SEFT) terhadap Depresi pada Lanjut Usia di PSLU Jombang di Pare Kediri. Tesis Fakultas Ilmu Keperawatan Universitas Padjadjaran

Ham, R.J., Sloane, P.D., \& Gregg. 2007. Primary care geriatric: a case based approach ( $5^{\text {th }} \quad$ ed). Philadelphia: Mosby.Inc

Jantos, M \& Kiat, H. 2007. Prayer as medicine: how much we learn. Medical Journal of Australia.186 (10): 51-53

Jayanti, Sedyowinarso, \& Madyaningrum. 2008. Faktorfaktor yang mempengaruhi tingkat depresi lansia di Panti Wredha "Wiloso Wredho" Purworejo. Jurnal Ilmu Keperawatan. 3(2): 133-138

Kurnianto, Purwaningsih \& Nihayati. 2011. Penurunan tingkat depresi pada lansia dengan pendekatan bimbingan spiritual. Media jurnal Ners 6(2)

Lane, JR. 2009. The Neurochemistry of countercoditioning: acupressure desensitization in pychotherapy. Energy Psychology 1(1): 31-44

Purbowinoto\&Kartinah.2011.Pengaruh terapi music terhadap perubahan tingkat depresi di PSTW Tresna Wreda unit budi luhur Kasongan Bantul Yogyakarta.

Stanley \& Beare. 2007. Buku ajar keperawatan gerontik. Jakarta: EGC

Trilistya, S. 2006. Tingkat depresi korban tanah longsor di Banjar Negara. Artikel Karya Tulis Ilmiah Fakultas Kedokteran Universitas Diponegoro. Semarang

Videbeck. 2008. Buku ajar keperawatan jiwa. Jakarta: EGC

Zainuddin, AF.2006. Spiritual Emotional Freedom Technique (SEFT) cara tercepat dan termudah mengatasi berbagai masalah fisik dan emosi. Jakarta: PT. Arga Publishing

Zainuddin, AF. 2012. SEFT Essentials the simplest way to get healed SEFTer handbook. Surabaya: SEFT Corporation 